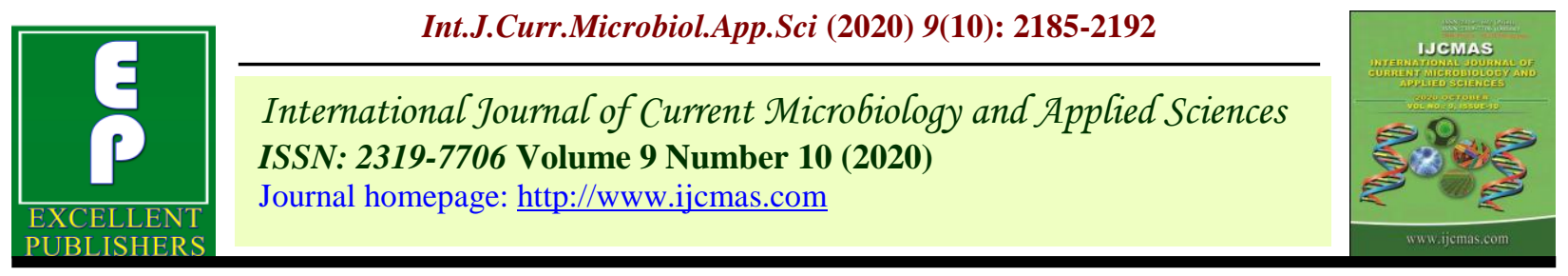

Original Research Article

https://doi.org/10.20546/ijcmas.2020.910.265

\title{
Genetic Divergence Analysis in Indian Mustard [Brassica juncea (L.) Czern \& Coss.]
}

\author{
Hari Om Meena ${ }^{1 *}$, P.K.P. Meena ${ }^{1}$, Khajan $\operatorname{Singh}^{1}$, H.P. Meena ${ }^{2}$ and Deepak Meena ${ }^{1}$ \\ ${ }^{1}$ Departmrnt of Genetics and Plant Breeding, ${ }^{2}$ Department of Agronomy, College of \\ Agriculture, Ummedganj, Agriculture University Kota (Rajasthan), India \\ *Corresponding author
}

\begin{tabular}{l}
\hline Ke y w o r d s \\
$\begin{array}{l}\text { Genetic divergence } \\
\text { analysis, Brassica } \\
\text { juncea, } \\
\text { Mahalanobis's D } \\
\text { statistics }\end{array}$ \\
\hline Article Info \\
$\begin{array}{l}\text { Accepted: } \\
\text { 17 September } 2020 \\
\text { Available Online: } \\
\text { 10 October } 2020\end{array}$ \\
\hline
\end{tabular}

\section{A B S T R A C T}

Genetic divergence analysis in 60 genotypes of Indian mustard [Brassica juncea (L.) Czern \& Coss.] by applying Mahalanobis's $\mathrm{D}^{2}$ statistics indicated the presence of wider genetic diversity among the material for 14 characters. The genotypes were grouped into eight clusters by Tocher's method. Cluster IV was the largest group with 18 genotypes, whereas cluster I was the second largest group consisting 16 genotypes followed in order by cluster VI (8 genotypes), cluster II ( 7 genotypes) and cluster III (6 genotypes). Two clusters, V and VIII comprised of two genotypes each cluster, while cluster VII comprised only one genotype (RH 406). The highest intra-cluster distance was observed for cluster VI (47.94). The highest inter-cluster distance was observed between cluster VIII and V (52.40). The maximum contribution to divergence was from seed yield per plant $(11.76 \%)$ in present investigation.

\section{Introduction}

Indian mustard [Brassica juncea (L.) Czern \& Coss] is an important Rabi season oilseed crop, belongs to family Cruciferae and genus Brassica. Indian mustard is a natural amphidiploid $(2 \mathrm{n}=36)$ a cross between Brassica rapa $(2 \mathrm{n}=20)$ and Brassica nigra $(2 \mathrm{n}=16)$. Mustard is largely self-pollinated but certain amount $(2-14 \%)$ of cross pollination may take place and is mainly grown in northern part of India. Rajasthan contributes $44.60 \%$ in area \& $52.05 \%$ in production of total rapeseed-mustard of India. Mustard crop required lower water requirement $(240-400$ $\mathrm{mm}$ ) for completing life cycle, therefore it is fits well for rain fed cropping systems. Four oleiferous brassica species viz. Brassica juncea, Brassica napus, Brassica rapa and Brassica carinata are cultivated in about 6.2 
million hectares area producing 9.3 million tons with a productivity of $1499 \mathrm{~kg} /$ hectare. Rajasthan has 2.38 million hectares cultivated area with the production of 3.95 million tons and productivity is $1656 \mathrm{~kg} /$ hectares. (Anonymous, 2018-2019). Rapeseed mustard are the third most important oilseed crops of the world and also the first most important oilseed crop of India.

The availability of genetic variability engraved in the breeding material plays major role in planning breeding programme to develop superior cultivars or hybrids. In general, the genetically divergent parents are utilized to obtain the desirable recombinants in segregating generations. Therefore, the present study was undertaken to estimate the genetic divergence Mahalanobis $\mathrm{D}^{2}$ technique in 60 genotypes of Indian mustard of diverse geographic origin and explore potential to evaluate the relationship of these genotypes based on quantitative trait data. Genetic divergence will further help in identifying genetically potential genotypes, which then can be utilized in creating valuable selectable variation.

\section{Materials and Methods}

The present study was administered at the Agricultural Research Station Ummedganj, Kota, Agriculture University Kota, Rajasthan, during Rabi 2019. Sixty genotypes of Indian mustard [Brassica juncea (L.) Czern \& Coss.] were planted in randomized block design with three replications. Each genotype was sown in 2 rows of 5.0-meter length with row to row and plant to plant spacing of $30 \mathrm{~cm}$ and 10 $\mathrm{cm}$, respectively. All the recommended agronomic practices for Indian mustard were followed to raise a healthy crop. The data was recorded on 14 quantitative characters viz., days to $50 \%$ flowering, days to maturity, plant height $(\mathrm{cm})$, number of primary branches per plant, number of secondary branches per plant, length of main axis $(\mathrm{cm})$, number of siliqua per plant, number of siliquae on main axis, length of siliqua $(\mathrm{cm})$, number of seeds per siliqua, 1000- seed weight (g), oil content $(\%)$, Harvest index (\%) and seed yield per plant (g).

\section{$D^{2}$ statistic}

Classification using $\mathrm{D}^{2}$ analysis of genetic divergence aims at grouping the genotypes precisely and objectively into various groups. In the present investigation simultaneous variations in all characters of 60 Indian mustard genotypes were tested for assessment of the nature of genetic divergence among them following Mahalanobis $\mathrm{D}^{2}$ statistics. The $\mathrm{D}^{2}$ values between the genotypes were obtained as the sum of squares of differences of the values of the corresponding transformed variables. For each pair of combination, the mean deviation

i.e. di $=Y_{i}^{1}-Y_{i}^{2}$, where $Y_{i}$ denotes the transformed variables $(\mathrm{i}=1,2,3,4$, $5 \ldots \ldots \ldots . . p)$ were calculated and the $\mathrm{D}^{2}$ was then calculated as sum of the squares of those deviations, i.e.

$$
\mathrm{D}^{2}=\sum\left(\mathrm{Y}_{\mathrm{i}}^{1}-\mathrm{Y}_{\mathrm{i}}^{2}\right)^{2}
$$

Where, $\mathrm{p}=$ Number of characters.

The significance of $\mathrm{D}^{2}$ values was tested by treating them as chi-square $\left(\chi^{2}\right)$ at $p$ degrees of freedom where $p$ is the number of characters considered.

\section{Grouping of genotypes by Tocher's method}

After arranging the $D^{2}$ values of all combinations of one genotype with the others in ascending order of magnitudes, the genotypes were grouped into a number of clusters by Tocher's method described by Rao (1952). The criterion used in this method was 
that any two varieties belonging to the same cluster, at least on an average, show a smaller $\mathrm{D}^{2}$-value than those belonging to two different clusters. Then inter-cluster and intracluster distances were calculated and their relationships were diagrammatically represented.

\section{Results and Discussion}

Sixty genotypes of Indian mustard, included in the present study were grouped into eight different clusters on the basis of genetic divergence or genetic closeness by $D^{2}$ following Tocher's method of clustering. The clustering pattern of the genotypes has been shown in Table 1. Cluster IV was the largest group of 18 genotypes, whereas cluster I was the second largest group consisting 16 genotypes grouped together. Cluster VI was the third largest cluster based on the genotypes (8 genotypes) followed by cluster II (7 genotypes) and cluster III (6 genotypes). Two clusters, V and VIII comprised of two genotypes each cluster. The remaining cluster VII comprised only one genotype (RH 406) indicating that this genotype is much more divergent than rest of the genotypes in the study. It was concluded that in general there was parallelism between genetic and geographic diversity. This view point has been supported by the work of Shathi et al., (2012), Khan et al., (2013) Kumar and Pandey (2013), Singh et al., (2014) Yong et al., (2014) and Tripati et al., (2019).

Maximum intra-cluster $\mathrm{D}^{2}$ value (47.94) was recorded in cluster VI among the eight intracluster distances, which revealed maximum genetic diversity among the genotypes of this group. Second highest average intra-cluster distance was observed by cluster II (40.21) followed in order by cluster III (40.11), cluster I (28.65), cluster VI (22.61), cluster V (19.12) and cluster VIII (14.01). The minimum average intra-cluster $\mathrm{D}^{2}$ value (0.00) was recorded for cluster VII (Table 2).

The inter-cluster distances ranged from 12.06 (between III and IV) to 52.40 (between V and VIII). The other clusters with high intercluster distances were V and VII (52.01) followed by cluster VI and VIII (46.81), III and V (46.37), VI and VII (42.20), IV and V (41.26) and I and V (41.05). The minimum average inter-cluster distance $\left(\mathrm{D}^{2}\right.$ value) was observed of between III and IV (12.06) followed by cluster I and VII (15.15), cluster I and IV (15.58) and cluster II and IV (15.69). The lowest inter cluster distances indicate that the genotype of these clusters had close relationship and hence, may not be emphasized upon to be used in hybridization programme. These results are somewhat in accordance with the findings of Singh et al., (2010), Singh et al., (2011), Kumar and Pandey (2013), Tudu et al., (2018) and Tripati et al., (2019).

Cluster III had higher mean values for most of the desirable characters like seed yield per plant (13.27) followed by number of primary branches per plant (8.23) number of secondary branches per plant (22.53), number of siliquae per plant (387.82), number of siliquae on main axis (46.82), number of seeds per siliqua (15.05) seed harvest index (23.70). The genotypes accommodate under cluster V were found desirable for seed yield per plant (15.52 g). Similarly, other traits like number of primary branches per plant (7.40), number of secondary branches per plant (20.95), number of siliquae per plant (397.57), number of siliquae on main axis (45.50) and number of seeds per siliqua (16.15) were also found desirable. 
Table.1 Distribution of 60 Indian mustard genotypes into different clusters

\begin{tabular}{|c|c|c|}
\hline Cluster & Number of Genotypes & Name of genotypes \\
\hline I & 16 & $\begin{array}{l}\text { Pusa Jai Kishan, NPJ-208, YSRL-9, Pusa } \\
\text { Mahak, PM-26, PM-28, Shivalik, Urvashi, JM-1, } \\
\text { Basanti, Vardaan, JM-1, Jagnnath, Giriraj, GM- } \\
\text { 1, RGN-236. }\end{array}$ \\
\hline II & 7 & $\begin{array}{l}\text { RH-725, PBR-91, Pusa Tarak, RH-30, Maya, } \\
\text { Krishna, Vaibhav. }\end{array}$ \\
\hline III & 6 & $\begin{array}{l}\text { RGN-229, Pusa Bahar, RH-51, Pusa Bold, } \\
\text { Varuna, DRMR-601. }\end{array}$ \\
\hline IV & 18 & $\begin{array}{l}\text { Rohini, PM-27, RGN-73, NRCDR-2, EJ-20, } \\
\text { RGN-48, RVM-2, RH-749, RH-781, } \\
\text { Vasundhara, JA-96, NPJ-206, RGN-34, RH-10, } \\
\text { RH-419, RH-904, RM-51, GM-3. }\end{array}$ \\
\hline $\mathbf{V}$ & 2 & RGN-303, Kranti. \\
\hline VI & 8 & $\begin{array}{l}\text { PDZ-1, GM-1, Ashirwad, Shivani, CS-54, Swarn } \\
\text { Jyoti, Kanti, GM-3. }\end{array}$ \\
\hline VII & 1 & RH-406. \\
\hline VIII & 2 & NRCHB-101, RH-819. \\
\hline
\end{tabular}

Table.2 Average intra-clusters (diagonal) and inter-cluster distance ( $\mathrm{D}^{2}$ value) in 60 genotypes of Indian mustard

\begin{tabular}{|c|c|c|c|c|c|c|c|c|}
\hline Cluster & I. & II. & III. & IV. & V. & VI. & VII. & VIII. \\
\hline I. & 28.65 & 18.64 & 22.15 & 15.58 & 41.05 & 36.03 & 15.15 & 18.10 \\
\hline II. & & 40.21 & 19.15 & 15.69 & 29.37 & 19.09 & 27.55 & 30.44 \\
\hline III. & & & 40.11 & $\mathbf{1 2 . 0 6}$ & 46.37 & 32.16 & 22.18 & 25.54 \\
\hline IV. & & & & 22.61 & 41.26 & 32.75 & 22.49 & 22.49 \\
\hline V. & & & & & 19.12 & 26.54 & 52.01 & $\mathbf{5 2 . 4 0}$ \\
\hline VI. & & & & & & $\mathbf{4 7 . 9 4}$ & 42.20 & 46.81 \\
\hline VII. & & & & & & & $\mathbf{0 . 0 0}$ & 16.78 \\
\hline VIII. & & & & & & & & 14.01 \\
\hline
\end{tabular}

* Figures in bold letters indicate maximum and minimum (intra/inter-cluster) values 
Table.3 Cluster means values of 60 genotypes for fourteen characters in Indian mustard

\begin{tabular}{|c|c|c|c|c|c|c|c|c|c|c|c|c|c|c|}
\hline Character & $\begin{array}{c}\text { Days to } \\
50 \% \\
\text { flowering }\end{array}$ & $\begin{array}{c}\text { Days to } \\
\text { maturity }\end{array}$ & $\begin{array}{l}\text { Plant } \\
\text { height } \\
(\mathrm{cm})\end{array}$ & $\begin{array}{c}\text { Number } \\
\text { of } \\
\text { primary } \\
\text { branches } \\
\text { per plant }\end{array}$ & $\begin{array}{l}\begin{array}{c}\text { Number } \\
\text { of } \\
\text { secondary } \\
\text { branches } \\
\text { per plant }\end{array} \\
\end{array}$ & $\begin{array}{c}\text { Length of } \\
\text { main axis } \\
(\mathbf{c m})\end{array}$ & $\begin{array}{l}\text { Number of } \\
\text { siliquae } \\
\text { per plant }\end{array}$ & $\begin{array}{c}\text { Number } \\
\text { of } \\
\text { siliquae } \\
\text { on main } \\
\text { axis }\end{array}$ & $\begin{array}{l}\text { Length } \\
\text { of } \\
\text { siliqua } \\
\text { (cm) }\end{array}$ & $\begin{array}{c}\text { Number } \\
\text { of seeds } \\
\text { per } \\
\text { siliqua }\end{array}$ & $\begin{array}{c}\text { 1000-seed } \\
\text { weight } \\
\text { (g) }\end{array}$ & $\begin{array}{c}\text { Oil } \\
\text { content } \\
(\%)\end{array}$ & $\begin{array}{c}\text { Harvest } \\
\text { index (\%) }\end{array}$ & $\begin{array}{c}\text { Seed } \\
\text { yield per } \\
\text { plant (g) }\end{array}$ \\
\hline I & 49.51 & 135.72 & 213.06 & 7.96 & 22.29 & 73.56 & 388.06 & 41.51 & 5.36 & 15.13 & 4.21 & 40.19 & 23.00 & 12.00 \\
\hline II & 50.01 & 133.79 & 224.86 & 8.59 & 19.91 & 74.50 & 374.19 & 42.36 & 5.72 & 14.24 & 5.23 & 39.83 & 22.35 & 13.31 \\
\hline III & 51.47 & 135.62 & 231.33 & 8.23 & 22.53 & 84.60 & 387.82 & 46.82 & 5.27 & 15.05 & 4.17 & 40.77 & 23.70 & 13.27 \\
\hline IV & 49.08 & 135.76 & 228.00 & 8.20 & 22.16 & 73.83 & 388.71 & 45.32 & 5.67 & 14.72 & 4.56 & 40.91 & 21.18 & 11.63 \\
\hline V & 53.50 & 139.35 & 221.50 & 7.40 & 20.95 & 57.20 & 397.57 & 45.50 & 4.53 & 16.15 & 3.05 & 38.83 & 20.69 & 15.52 \\
\hline VI & 48.69 & 129.56 & 229.13 & 7.43 & 19.61 & 78.78 & 357.28 & 45.49 & 5.49 & 15.81 & 4.50 & 39.40 & 24.25 & 11.19 \\
\hline VII & 52.70 & 136.00 & 211.00 & 11.30 & 22.70 & 85.10 & 393.50 & 45.00 & 6.46 & 16.80 & 4.64 & 41.62 & 26.89 & 9.28 \\
\hline VIII & 60.65 & 132.00 & 213.50 & 6.95 & 19.15 & 75.25 & 399.35 & 48.10 & 4.60 & 15.30 & 4.14 & 41.45 & 24.47 & 12.70 \\
\hline
\end{tabular}


Table.4 Relative contribution of different characters to genetic divergence among 60 genotypes of Indian mustard (Brassica juncea L.)

\begin{tabular}{|c|l|c|}
\hline S. No. & Character & \% contribution \\
\hline $\mathbf{1 .}$ & Days to 50\% flowering & 5.53 \\
\hline $\mathbf{2 .}$ & Days to maturity & 2.76 \\
\hline $\mathbf{3 .}$ & Plant height $(\mathrm{cm})$ & 4.41 \\
\hline $\mathbf{4 .}$ & Number of primary branches per plant & 8.04 \\
\hline $\mathbf{5 .}$ & Number of secondary branches per & 9.75 \\
\hline & plant & 6.99 \\
\hline $\mathbf{6 .}$ & Length of main axis $(\mathrm{cm})$ & 6.47 \\
\hline $\mathbf{7 .}$ & Number of siliquae per plant & 7.27 \\
\hline $\mathbf{8 .}$ & Number of siliquae on main axis & 8.07 \\
\hline $\mathbf{9 .}$ & Length of siliqua $(\mathrm{cm})$ & 6.32 \\
\hline $\mathbf{1 0 .}$ & Number of seeds per siliqua & 11.09 \\
\hline $\mathbf{1 1 .}$ & 1000-seed weight $(\mathrm{g})$ & 1.93 \\
\hline $\mathbf{1 2 .}$ & Oil content $(\%)$ & 9.61 \\
\hline $\mathbf{1 3}$ & Harvest index $(\%)$ & 11.76 \\
\hline $\mathbf{1 4}$ & Seed yield per plant $(\mathrm{g})$ & \\
\hline
\end{tabular}

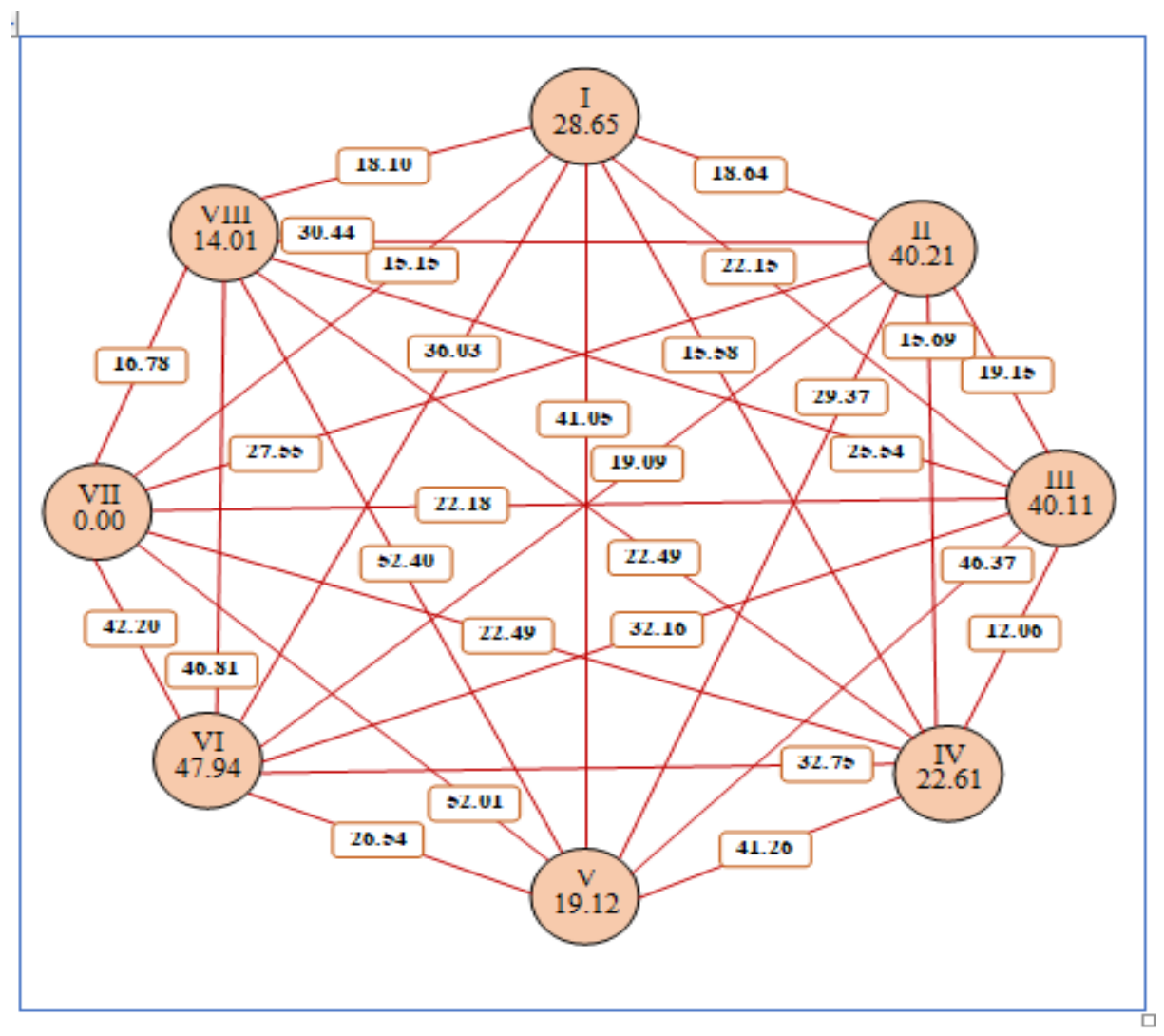

Figure 01: Cluster diagram showing average intra-cluster \& inter-cluster genetic distances by Tocher's methods in Indian mustard (not to scale) 
The contribution of various characters under study towards the expression of genetic divergence is presented in Table 4 . It is clear from the table that on the basis of average $\mathrm{D}^{2}$ the highest contribution to divergence was from seed yield per plant $(11.76 \%)$ followed by 1000 -seed weight $(11.09 \%)$. The relative contribution of different character to the total divergence in order was number of secondary branches per plant $(9.75 \%)$, harvest index $(9.61 \%)$, length of siliqua $(8.07 \%)$, number of primary branches per plant (8.04 \%), number of siliquae on main axis $(7.27 \%)$, length of main axis (6.99\%), number of siliquae per plant $(6.47 \%)$ and number of seeds per siliqua $(6.32 \%)$. Oil content contributed least towards the total divergence $(1.93 \%)$ followed by days to maturity $(2.76$ $\%$ ), plant height $(4.41 \%)$ and days to $50 \%$ flowering $(5.53 \%)$. These results are in conformity with the findings of Khan et al., (2013), Kumar et al., (2013), Shekhawat et al., (2014), Kumari and Kumari (2018) and Rout et al., (2019).

\section{References}

Anonymous, (2018-19). Economic Survey, Government of India, Ministry of Finance, Department of Economic Affairs Government of India.

Anonymous, (2018-19). Rajasthan Agriculture statistics at a Glance, Commissionerate of Agriculture, Rajasthan, Jaipur.

$\mathrm{Fu}$, Yong, Bi., Cheng, Bi. Fang. and Peterson G.W. (2014). Genetic diversity analysis of yellow mustard (Sinapis alba L.) germplasm based on genotyping by sequencing, 61(3): 579-594.

Khan, M.H., Ali, M.M., Vhuiyan, S.R. and Mahmud, F. (2013). Genetic divergence in rapeseed-mustard (Brassica rapa L.). Bangladesh Journal of Agricultural Research, 38(3): 417-423.

Kumar, B. and Pandey, A. (2013). Diversity
Analysis in Indian mustard (Brassica juncea L.). Madras Agricultural Journal, 100(3): 62-66.

Kumari. A. and Kumari. V. (2018). Studies on genetic diversity in Indian mustard (Brassica juncea L.) for morphological characters under changed climate in the mid-hills of Himalayas The Pharma Innovation Journal, 7(7): 290-296.

Mahalanobis, P.C. (1936). On the generalized distance in statistics Proceedings of the National Institute of Sciences of India, 2(1): 49-55.

Rao, CR. (1952). Advanced statistical methods in biometric research. John Wiley and Sons Inc New York, 390.

Rout, S., Das, A., Sur, B., Umamaheswar, N., Sadhu, S., Ghimiray, T. S., Mondal, H. A., Hijam, L., Chakraborty, M. and Roy S. K. (2019). Genetic divergence in Indian mustard (Brassica juncea L.) under sub-Himalayan region. Journal of Crop and Weed, 15(2): 18-24.

Shathi, D.A., Arifuzzaman, M., Biswas, B.K., Hasanuzzaman, M. and Azad, A.K. (2012). Genetic divergence in mustard (Brassica spp. L.). African Journal of Plant Science, 6(8): 239-243.

Shekhawat, N., Jadeja, G. C., Singh, J. and Ramesh. (2014). Genetic diversity analysis in relation to seed yield and its component traits in Indian mustard (Brassica juncea L.). The Bioscan Journal, 9(2):713-714.

Singh D, Arya R.K, Chandra N, Niwas R, Salisbury P. (2010). Genetic diversity studies in relation to seed yield and its component traits in Indian mustard (Brassica juncea L.). Journal of Oilseed Brassica, 1(1): 19-22.

Singh, M., Tomar, A., Mishra, C. N. and Srivastava, S.B.L. (2011). Genetic parameters and character association studies in Indian mustard (Brassica juncea L.). Journal of Oilseed Brassica, 2(1): 35-38. 
Singh, N.P., Sharma, P.K., Kumar, V., Kumar, V., And Malik, V.K. (2014). Genetic divergence analysis in Indian mustard (Brassica juncea L.). Annals of Biology, 30(2): 296-298.

Tripathi, A., Singh, M. and Tomar, A. (2019). Genetic diversity analysis for qualitative and quantitative traits in Indian mustard
(Brassica juncea L.). The Pharma Innovation Journal, 8(1): 637-639.

Tudu, V.K., Kumar, A. and Rani, V. (2018). Genetic divergence in Indian mustard (Brassica juncea L.) based on yield attributing traits. Journal of Pharmacognosy and Phytochemistry, 2093-2096.

\section{How to cite this article:}

Hari Om Meena, P.K.P. Meena, Khajan Singh, H.P. Meena and Deepak Meena. 2020. Genetic Divergence Analysis in Indian Mustard [Brassica juncea (L.) Czern \& Coss.]. Int.J.Curr.Microbiol.App.Sci. 9(10): 2185-2192. doi: https://doi.org/10.20546/ijcmas.2020.910.265 